\title{
Dugong dugon feeding in tropical Australian seagrass meadows: implications for conservation planning
}

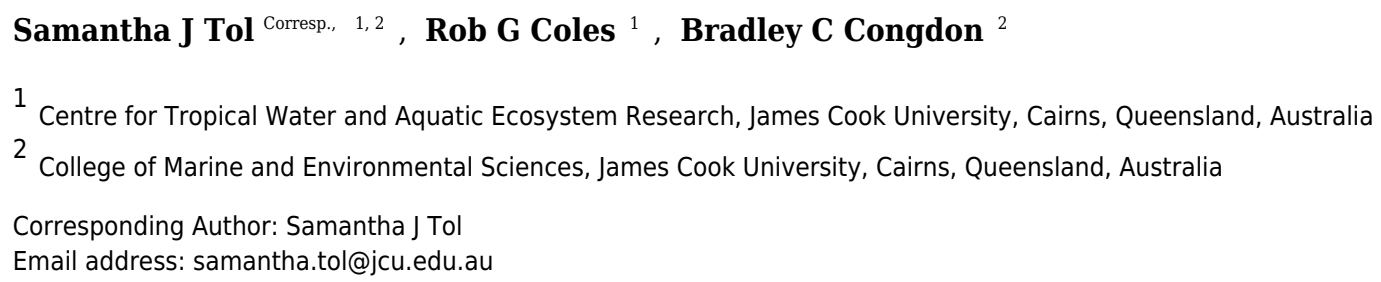

Dugongs (Dugong dugon) are listed as vulnerable to extinction due to rapid population reductions caused in part by loss of seagrass feeding meadows. Understanding dugong feeding behaviour in tropical Australia, where the majority of dugongs live, will assist conservation strategies. We examined whether feeding patterns in intertidal seagrass meadows in tropical north-eastern Australia were related to seagrass biomass, species composition and/or nitrogen content. The total biomass of each seagrass species removed by feeding dugongs was measured and compared to its relative availability. Nitrogen concentrations were also determined for each seagrass species present at the sites. Dugongs consumed seagrass species in proportion to their availability, with biomass being the primary determining factor. Species composition and/or nitrogen content influenced consumption to a lesser degree. Conservation plans focused on protecting high biomass intertidal seagrass meadows are likely to be most effective at ensuring the survival of dugong in tropical north-eastern Australia 
3

4 Samantha J Tol. ${ }^{1,2}$, Rob G Coles ${ }^{1}$ and Bradley C Congdon ${ }^{2}$

5

6 1. Centre for Tropical Water and Aquatic Ecosystems Research (TropWATER), James Cook

7 University, Cairns, QLD, 4870, Australia

8 2. College of Marine and Environmental Sciences, James Cook University, Cairns, QLD, 4870,

9 Australia

10 


\section{Abstract}

12 Dugongs (Dugong dugon) are listed as vulnerable to extinction due to rapid population reductions caused in part by loss of seagrass feeding meadows. Understanding dugong feeding

14 behaviour in tropical Australia, where the majority of dugongs live, will assist conservation

15 strategies. We examined whether feeding patterns in intertidal seagrass meadows in tropical

16 north-eastern Australia were related to seagrass biomass, species composition and/or nitrogen

17 content. The total biomass of each seagrass species removed by feeding dugongs was measured

18 and compared to its relative availability. Nitrogen concentrations were also determined for each

19 seagrass species present at the sites. Dugongs consumed seagrass species in proportion to their

20 availability, with biomass being the primary determining factor. Species composition and/or

21 nitrogen content influenced consumption to a lesser degree. Conservation plans focused on

22 protecting high biomass intertidal seagrass meadows are likely to be most effective at ensuring

23 the survival of dugong in tropical north-eastern Australia. 
26

27

28

29

30

31

32

\section{Introduction}

Dugongs (Dugong dugon) are the last surviving species within the family Dugongidae (Grech et al. 2011b; Marsh \& Lefevbre 1994) and are listed as 'vulnerable to extinction' by the IUCN Red List of Threatened Species (IUCN 2011). Dugong diet consists predominantly of seagrass and they are restricted in range to tropical and subtropical locations of the Indo-west Pacific where shallow seagrass meadows are common (Marsh et al. 1982; Marsh et al. 2011). Throughout most of this distribution they occur as small relatively isolated populations (Allen et al. 2004), with the only substantial populations being found in northern Australian waters (Marsh et al. 2012; Marsh \& Lefevbre 1994; Marsh et al. 2011). Since the 1960s, dugong populations along the east coast of Queensland, Australia, have declined by 95 per cent (Marsh et al. 2005; Marsh \& Lefevbre 1994), leading to calls for the species status to be up listed to critically endangered (Marsh et al. 2005; Marsh et al. 2011). In eastern Queensland much of the decline has occurred since 2005 , and has been attributed to substantial reductions in seagrass availability associated with recent extreme weather events (McKenna et al. 2015; McKenzie et al. 2012; Sobtzick et al. 2012).

In Australia, studies of dugong feeding in the subtropical, subtidal meadows of south-east Queensland suggest that dugong feeding preferences are based on the nutritional quality and digestibility of seagrass as a food source (Marsh et al. 2011; Preen 1995; Sheppard et al. 2010). These studies observed preferences for Halophila ovalis and Halodule uninervis and concluded that these species are targeted because of their greater nitrogen content, combined with a general preference for low biomass strands, due to lower concentrations of fibre (Lanyon 1991; Mellors 
48 et al. 2005; Preen 1995; Sheppard et al. 2007). This is consistent with nitrogen being a major

49 limiting nutrient for all Sirenians, including dugongs (Lanyon 1991). Research comparing

50 nutrient content also found that intertidal seagrass plants have higher levels of starch and are

51 more digestible than subtidal plants (Sheppard et al. 2008; Sheppard et al. 2007). Combined,

52 these studies suggest that intertidal seagrass meadows with species of high available nitrogen

53 should be preferred feeding grounds (Preen 1998; Sheppard et al. 2010). In contrast, studies of

54 dugong feeding in other tropical regions regularly observe feeding across all species present,

55 with the exception of Enhalus acoroides (Adulyanukosol \& Poovachiranon 2006; André et al.

56 2005; Aragones 1994; De Iongh et al. 2007). The differences in dugong feeding behaviour

57 observed at the edge of their range in south-east Queensland may be due to seagrass biodiversity

58 being lower, combined with dietary requirements for living in colder waters (Preen 1992; Preen

59 1995). Therefore, the applicability of findings from south-east Queensland to intertidal feeding

60 areas in tropical Australia, or to other tropical feeding grounds is unclear.

61

62 Many factors may influence dugong feeding choice. Alterations in feeding preferences and

63 behaviour could occur if the animal is under stress, such as from temperature at the edge of their

64 distributional range, or hunting pressures (Anderson 1994; Anderson 1998; Anderson \& Birtles

65 1978; Brownell et al. 1981; Marsh et al. 2011; Wirsing et al. 2007). Other important factors

66 include the physical characteristics of the marine environment such as depth, sediment type,

67 water temperature and water currents, or biological factors such as the seagrass species type,

68 biomass above and below ground, digestibility, nutrient content and the age of the plants

69 (Aragones et al. 2006; Marsh et al. 2011; Preen 1995). Theoretically, dugong feeding behaviour

70 is thought to follow an optimal foraging strategy, in which feeding site selection is based on 
71 maximum energy gained with minimal energy expended (Aragones et al. 2006; Preen 1995;

72 Sheppard et al. 2007). Adding to this complexity, is that feeding location and the timing of

73 feeding may also be influenced by external factors such as the possibility of stranding, presence

74 of predators, human disturbance, seasonal changes or simply familiarity with the area and its

75 seagrass meadow history (Marsh et al. 2011). Understanding the reason dugongs choose to feed

76 in some locations and not others, and/or the importance of specific seagrass species or meadows,

77 is important for developing appropriately targeted conservation of high quality dugong feeding

78 habitats.

79

80 In the present study, we examine a sub-set of potential factors influencing the selection of

81 seagrass species by dugongs feeding in intertidal seagrass meadows in tropical north

82 Queensland, so as to improve our understanding of the relationship between dugong and their

83 seagrass food. These factors include seagrass species presence, nitrogen content and relative

84 biomass.

85

86 Materials \& Methods

87

88 Study site

89 Six mixed species coastal intertidal seagrass meadows in the Great Barrier Reef (GBR), north

90 Queensland, were selected based on the number of seagrass species present, a lack of direct

91 human disturbance, and that dugong feeding has been historically recorded at these sites (Davies

92 \& Rasheed 2016; McKenzie et al. 2014) (Table 1). Three meadows were located near Cairns

93 and three in the Townsville region (Fig. 1). The Cairns sites included a reef platform at Double 
94 Island located two kilometres offshore from the Cairns coastal beaches, Yule Point beach and

95 Cooya beach north of Cairns. The Townsville sites were at Cockle Bay on Magnetic Island

96 located seven kilometres off the coast of Townsville, Shelley Beach at Cape Pallarenda located

97 north-west of the Townsville harbour, and Bowling Green Bay, an intertidal flat south-east of

98 Townsville. Data on seagrass characteristics were collected from all six meadows and dugong

99 feeding data were collected from three meadows; Cockle Bay, Cape Pallarenda and Double

100 Island. The meadows studied, and meadows in the vicinity of the study sites, had consistent

101 seagrass cover over an extensive period of time (Coles 1992), or had recovered quickly after

102 tropical storm-related losses (Davies et al. 2013). All sites where dugong feeding data were

103 collected had sand with shell sediment and all showed evidence of dugongs feeding (excavated

104 feeding trails) on above and below ground seagrass biomass (Fig. 2). Dugongs have been

105 recorded cropping on seagrass leaves and not leaving any obvious feeding trail (Preen 1992).

106 However, there was no evidence of cropping at our sites and cropping is not common in soft

107 sediment seagrass meadows (Johnstone \& Hudson 1981; Preen 1992).

108

109

Data Collection

110 Seagrass meadow characteristics and dugong feeding trails were measured at low tides during

111 the senescent period between May and August 2012. Dugong feeding trail data were collected

112 fortnightly at Double Island and Cockle Bay and monthly at Pallarenda; the Pallarenda site was

113 inaccessible during neap tides. The meadows sampled were similar in species composition and

114 biomass and representative of the region (Coles 1992; Davies et al. 2013; McKenzie et al. 2012).

115 All data collection were authorised under 'Marine Parks Permit (G13/36179.1)' and 'General

116 Fisheries Permit (168652)'. 
118 To measure the total seagrass removed by foraging dugong, it was necessary to measure the

119 unseen below ground component of the seagrass plant; the roots and rhizomes. This was

120 undertaken by determining whether a linear relationship was present between the above ground

121 (leaves and stems) and the below ground component of the seagrass species. Above and below

122 ground seagrass samples were collected haphazardly across all sites, using a cylindrical pipe

123 corer measuring $150 \mathrm{~mm}$ in diameter. Below ground components were sampled to a depth of

$124100 \mathrm{~mm}$, ensuring the inclusion of all below ground plant biomass likely to be excavated by a

125 dugong (Anderson \& Birtles 1978; Heinsohn et al. 1977; Preen 1992). Samples were collected

126 for each seagrass species present at each site, with a minimum of 12 samples collected per site

127 (Triola \& Triola 2006). Samples were washed, epiphytes removed and plants separated into

128 above and below ground components before drying at $40{ }^{\circ} \mathrm{C}$ for 48 hours or until a

129 stable/consistent dry weight was reached. Dry weights were measured separately for above and

130 below ground components of the plant to generate an equation to estimate below ground weights

131 from above ground weights, when only above ground biomass estimates were available.

132

133 Digestible nitrogen was determined for each species that were present at the three foraging sites, 134 and one non-foraging site, to create a predictive hierarchy. Nitrogen samples were collected 135 haphazardly within the four different seagrass meadows. Samples for each species within a site

136 were pooled to obtain the minimum dry weight necessary for nitrogen extraction. Nitrogen 137 weight (milligrams) per seagrass weight (grams dry weight) was determined colorimetrically by 138 the salicylate-hypochlorite method (Baethgen \& Alley 1989). Total nitrogen concentrations 139 were measured as the mean of three absorbance runs, read at $655 \mathrm{~nm}$. 
141 Dugong feeding trail measurements were from $1 \mathrm{~m}^{2}$ quadrats randomly selected within a larger

14250 x 50 m plot located where feeding trails occurred; a different plot was sampled each trip.

143 Random selection of $1 \mathrm{~m}^{2}$ quadrats at each site was continued until a minimum of 10 feeding and

14410 non-feeding quadrats were obtained for each sampling trip. In each $1 \mathrm{~m}^{2}$ quadrat, species-

145 specific seagrass cover and above ground biomass was estimated using a visual estimation

146 method (Mellors 1991). To estimate the quantity of seagrass removed by dugongs, we estimated

147 (using the Mellors (1991) method) the biomass of seagrass within the quadrat immediately

148 adjacent to the trail, equivalent in area to that of the trail. Although dugongs are likely to leave

149 some plant material behind when feeding, in our experiment it was assumed for comparative

150 purposes that whole plants were removed (Anderson \& Birtles 1978; Preen 1992). The length

151 and width of each feeding trail was recorded to $\pm 0.5 \mathrm{~cm}$. Three measurements of width were

152 taken, one at each end of the trail and one in the middle, to calculate a mean width. Species-

153 specific above ground biomass for each feeding trail was calculated using the feeding trail

154 surface area and the value of the corresponding proportion of above ground biomass for each of

155 the seagrass species.

156

157 To avoid damage to the site by destructive sampling, the total biomass available and that

158 removed by dugongs were calculated from above ground biomass estimates (Mellors 1991) using

159 derived regression equations from the core samples; equations were applied for each species at

160 each site. Data collected on Cymodocea serrulata and C. rotunda were combined into

161 Cymodocea spp., as these two species are morphologically similar (Green \& Short 2003;

162 Waycott et al. 2004). 
164 Statistical analysis

165 Data were transformed using log or square root transformations to ensure normality and 166 homogeneity of variances. Analyses of covariance (ANCOVA) were performed to determine 167 whether the relationship between above ground to below ground plant biomass differed across 168 sites for $H$. ovalis and H. uninervis; with above ground biomass $\left(\mathrm{g} / \mathrm{DW} \mathrm{m}^{2}\right)$ as the independent, 169 below ground plant biomass $\left(\mathrm{g} / \mathrm{DW} \mathrm{m}^{2}\right)$ as the dependent, and site as the covariate variable.

170 Where data did not meet the assumptions of a standard regression analysis, a Generalized Least171 Squares analysis was used (Whitlock \& Schluter 2008). To determine whether nitrogen differed 172 amongst the dominant seagrass species present (H. ovalis and H. uninervis), and to test for 173 differences in whole plant nitrogen content within each site, the data was analysed with an 174 ANOVA. A non-parametric test, Wilcoxon rank sum, was used to determine if there were any 175 differences between nitrogen concentrations for Cymodocea spp. in the two sites where it was 176 present.

178 To analyse dugong feeding patterns, a Linear Mixed Effects Model was applied with 'total

179 biomass removed' as the dependent variable. The three intertidal seagrass meadows represented 180 random factors in the analysis, enabling variation between sites to be accounted for during the 181 partitioning of variance. 'Seagrass biomass available' and 'seagrass species present' were 182 entered as fixed factors, and the multiple samples obtained at each site over the four months of 183 data collection were entered as replicates. Standard residual diagnostic tests were performed to 184 determine whether the statistical test was appropriate. To ensure a comparative test for all 
185 species present at the feeding sites, an upper limit of $2.80 \mathrm{~g} / \mathrm{DW} \mathrm{m}^{2}$ was applied to remove 186 outliers from the data.

187

\section{Results}

Estimating below ground biomass for seagrass species

191

192

193

194

195

196

197 198

200

201

202

203

204

205

206

207

There was a significant positive relationship between above and below ground plant biomass for most seagrass species across all sites (Cymodocea spp., H. ovalis, H. uninervis and Syringodium isoetifolium) (see Supplementary Material S1). Negative y-intercepts for some species suggest those equations are poor predictors of below ground biomass when above ground biomass was low (see Supplementary Material S2). Thalassia hemprichii had no significant relationship between above and below ground biomass (see Supplementary Material S1). The below ground component of this plant is deeper than 100 millimetres, (Green \& Short 2003; Waycott et al. 2004) so all the below ground component would not have been included in our collections. In the analysis of site-specific effects on the two predominant species, H. ovalis and $H$. uninervis, the relationship between above and below ground biomass was significantly different among sites (ANCOVA: H. ovalis: $\mathrm{F}_{4,102}=21.54, \mathrm{p}=>0.001 ;$ H. uninervis: $\mathrm{F}_{5}, 131=14.93, \mathrm{p}=>0.001$, see Supplementary Material S1).

Nitrogen concentration of seagrass species

$H$. ovalis and $H$. uninervis had the highest median nitrogen concentrations of the five species at each site. The nitrogen concentration found in H. ovalis and H. uninervis were not significantly different (ANOVA: $F=0.29005_{1,3}, \mathrm{p}=0.59$, Fig. 3a), however nitrogen varied significantly 
208 across sites (ANOVA: $\mathrm{F}=31.94_{, 3}, \mathrm{p}=>0.001$, Fig. 3a); with $H$. uninervis having higher

209 nitrogen concentrations in Yule Point and Pallarenda. Cymodocea spp. did not differ in nitrogen

210 concentration across the two sites where it was present (Wilcoxin rank sum: $Z=12, n=3, p=$

211 0.70, Fig. 3b). Total nitrogen concentrations varied among species and sites (Table 2). The

212 hierarchal order of whole plant nitrogen concentration (from highest to lowest) for the five

213 seagrass species sampled across all sites was:

214

Halophila ovalis $=$ Halodule uninervis $>$ Syringodium isoetifolium $>$ Thalassia hemprichii $>$

Cymodocea spp.

Dugong feeding patterns

With the exception of $S$. isoetifolium, each seagrass species was consumed in increasing amounts as the available biomass of that species increased (Linear Mixed-Effect model fit by REML, Biomass: $F_{1,223}=373.6722, p>0.001$; Fig. 4). However significant differences were observed in the rate at which each of the species was consumed at a given biomass (Linear Mixed-Effect model fit by REML, Species: $\mathrm{F}_{4,223}=10.5534, \mathrm{p}>0.001$; Fig. 4). There was no significant interaction effect in this analysis (Linear Mixed-Effect model fit by REML, Biomass*Species: $\mathrm{F}_{4,223}=1.6517, \mathrm{p}=0.1623$; Fig. 4), indicating that no seagrass species was consumed at a relatively greater rate when other seagrass species were being consumed. Pair-wise comparisons

227 between species showed that Cymodocea spp., H. ovalis, H. uninervis, and S. isoetifolium were consumed at equivalent rates per available biomass, while $T$. hemprichii was consumed at greater amounts for a given available biomass (Fig. 4). Sample sizes for both $S$. isoetifolium and $T$. hemprichii were small relative to those for the other species and so analyses and interpretations 
231 for these seagrasses species are less reliable. These results did not change for Cymodocea spp.,

232 H. ovalis and H. uninervis when $S$. isoetifolium and T. hemprichii were removed from the

233 analysis.

234

235

\section{Discussion}

236

237 Our study demonstrated that in the Cairns and Townsville regions of tropical north Queensland, 238 Australia, the ingestion of seagrass species by feeding dugongs increased in proportion to their 239 availability for four of the five species, and that these species were consumed at equivalent rates 240 given their available biomass. This indicates that feeding patterns at our sites were influenced 241 most strongly by the available plant biomass and only to a lesser degree by species composition 242 and/or by nitrogen content. Dugongs did not selectively feed on higher nitrogen content species, 243 or in lower biomass areas, as they do elsewhere (Preen 1995; Sheppard et al. 2007). This result 244 was further supported by less feeding trails in other low biomass seagrass meadows close to the 245 study sites (pers obs. Tol 2012). H. ovalis and H. uninervis were found to be the most common 246 seagrass species available at all sites and were also the species with the highest nitrogen content.

247 This made it difficult to separate feeding targeted at increased biomass from feeding that may

248 have been targeted at high nitrogen content. However, greater feeding on T. hemprichii, a 249 species with a lower nitrogen content, further supports our contention that nitrogen plays a lesser 250 role in influencing feeding site use than biomass.

251

252 Overall, our results imply that biomass per se is the most important factor determining dugong

253 feeding patterns in tropical north Queensland and that feeding at our sites occurs in high biomass 
254 locations, independent of species composition or nitrogen content. This finding agrees with

255 dugong mouth and stomach content analyses and feeding trail observations in the Torres Strait

256 and south-east Asian regions of the tropics, where biomass was also considered to be a key factor

257 determining feeding behaviour (Adulyanukosol \& Poovachiranon 2006; André et al. 2005;

258 Aragones 1994; Johnstone \& Hudson 1981). However, nitrogen concentrations of seagrasses in

259 the Torres Straits were not significantly different among species (Sheppard et al. 2008), and

260 foraging dugongs would not need to select for higher nitrogen. This effect in the Torres Striat

261 was confounded by differences in digestibility of seagrasses (Sheppard et al. 2008). Digestibility

262 was not measured in our study, but it is unlikely to be an effect as the most digestible seagrass

263 species (H. ovalis) (Sheppard et al. 2008) was not the most selected species at our study sites.

265 Intertidal seagrass meadows dominated by H. ovalis and/or H. uninervis are considered

266 preferential sub-tropical feeding meadows, due to the greater nitrogen content of these species

267 (Lanyon 1991; Mellors et al. 2005; Preen 1998; Sheppard et al. 2010). Our results contradict this

268 theory, suggesting that in eastern Australia dugong feeding behaviour changes with latitude.

269 Regional differences along the Queensland coast in the choice of seagrass species for food and

270 feeding behaviour is likely, as the dugong population is distributed along a wide latitudinal

271 range. Dugongs have shown seasonal changes in their feeding characteristics when living at the

272 edge of their range (Anderson 1994; Anderson 1998; Sheppard et al. 2006), suggesting that

273 feeding behaviour may also have location/site and seasonal influences. The lack of consistent

274 feeding preference associated with seagrass species, biomass, digestibility and/or nutrients in

275 other studies (André et al. 2005; Johnstone \& Hudson 1981; Preen 1995; Sheppard et al. 2006), 
276 emphasises this potential flexibility and so suggest that our results are relevant only in the tropics

277 and/or at local and regional scales. .

278

279 Dugong feeding trails are the best non-invasive evidence of feeding, and are common in many

280 tropical intertidal regions, including the GBR and sub-tropical locations (such as Morton Bay

281

282

283

284

285

286

287

288

289

290

291

292

293

294

295

296

297

and Hervey Bay in south-east Queensland and Shark Bay on the western coast of Australia)

(Aragones 1994; De Iongh et al. 2007; Preen 1995). These mostly nearshore sites are also the preferred locations for boating, fishing, hunting and coastal infrastructure development (Grech et al. 2011a), and dugongs may actively avoid these seagrass meadows for the safety of lower biomass sub-tidal meadows (Brownell et al. 1981; Wirsing et al. 2007). Many seagrass meadows are identified as being at 'high risk' from anthropogenic factors due to increased coastal development (Grech et al. 2011a; Orth et al. 2006) and the health and protection of our near-shore coastal seagrass meadows is vital for their survival. The decline in seagrass cover in late 2010 and early 2011 along the tropical east Queensland coast, especially between Cairns and Townsville and their patchy recovery (McKenna et al. 2015), has emphazised the importance of a better understanding of the characteristics of meadows being grazed by dugong at local and regional scales. Currently in the GBR there are no areas specifically set aside where seagrass meadows are protected for dugong feeding, either from direct impacts or from the influence of adjacent coastal processes. Our research identifies areas in the Cairns to Townsville region where there have been losses in recent times, and where greater levels of protection would be desirable. Advice at appropriate scales to Marine Park and coastal planners that is tailored to regional specific needs, including identifying which areas of seagrass are best able to support 
298 dugong populations, is vital for the successful protection of both dugong and their seagrass food 299 source.

300

301 In our study sites, high biomass seagrass meadows were the preferred feeding grounds, with 302 seagrass species and nitrogen content important only to a lesser degree. Measuring the chemical composition of seagrass plants is time consuming and expensive. In comparison, rapid seagrass survey techniques are readily available to estimate area, biomass and species composition of meadows (Short \& Coles 2001). The implications of our results, at least for Australian tropical regions, is that these existing rapid seagrass survey techniques can be effectively used to locate and prioritize dugong seagrass feeding grounds for inclusion in management plans. Dugongs are almost obligate feeders on seagrasses and an optimal conservation approach must include strategies to protect both the animals as well as their food source (Marsh et al. 2011), and these approaches may have to be regionally specific to be effective.

\section{Conclusions}

314 Studying dugong feeding trails are a useful non-invasive tool in understanding feeding

315 behaviour. We found in our tropical sites high biomass seagrass meadows were the preferred 316 feeding meadows, with seagrass species and nitrogen only important to a lesser degree.

317 Management protection and conservation planning for dugongs and dugong seagrass feeding 318 resources needs to be regionally specific for tropical regions. Existing rapid seagrass survey 319 techniques could effectively and economically use seagrass biomass as a surrogate for rapid 320 identification of important dugong feeding meadows for protection in tropical Australia. 
322 Supporting material

323

324 Regression graphs and results used for predicting the below ground biomass from the above 325 ground biomass of seven different seagrass species (Appendix S1 and S2) are available online.

326 The authors are solely responsible for the content and functionality of these materials. Queries 327 should be directed to the corresponding author.

328

329 Acknowledgements

330

331 Advice provided by Helene Marsh, Will Edwards and Paul York at James Cook University, and 332 the reviewers was greatly appreciated and helped to improve the quality of this paper. 


\section{References}

334 Adulyanukosol K, and Poovachiranon S. 2006. Dugong (Dugong dugon) and seagrass in Thailand: present status and future challenges. Proceedings of the 3rd International Symposium on SEASTAR2000 and Asian Bio-logging Science (The 7th SEASTAR2000 workshop). Kyoto, Japan: Kyoto University. p 41-50.

Allen S, Marsh H, and Hodgson A. 2004. Occurrence and conservation of the dugong (Sirenia: Dugongidae) in New South Wales. Proceedings of the Linnean Society of NSW 125:211-216.

Anderson P. 1994. Dugong distribution, the seagrass Halophila spinulosa, and thermal environment in winter indeeper waters of eastern Shark Bay, WA. Wildlife Research 21:381-387.

Anderson P. 1998. Shark Bay dugongs (Dugong dugon) in summer. II: Foragers in a Halodule-dominated 10.1071/WR9940381 community. Mammalia 62:409-426. 10.1515/mamm.1998.62.3.409

Anderson P, and Birtles A. 1978. Behaviour and Ecology of the Dugong, Dugong dugon (Sirenia): Observations in Shoalwater and Cleveland Bays, Queensland. Wildlife Research 5:1-23.

André J, Gyuris E, and Lawler I. 2005. Comparison of the diets of sympatric dugongs and green turtles on Research 21:709-717. 10.1071/WR9940709

Aragones L, Lawler I, Foley W, and Marsh H. 2006. Dugong grazing and turtle cropping: grazing optimization in tropical seagrass systems? Oecologia 149:635-647. 10.1007/s00442-006-0477-1

Aragones L. 1994. Observations on dugongs at Calauit Island, Busuanga, Palawan, Phillipines. Wildlife the Orman Reefs, Torres Strait, Australia. Wildlife Research 32:53-62. 10.1071/WR04015 soil and plant Kjeldahl digests. Communications in Soil Science \& Plant Analysis 20:961-969. $10.1080 / 00103628909368129$ 
357 Brownell R, Anderson P, Owen R, and Ralls K. 1981. The status of dugongs at Palau, an isolated island

358

359

360

361

362

363

364

365

366

367

368

369

370

371

372

373

374

375

376

377

378

379

380

group. In: Marsh H, editor. The dugong Proceedings of a seminar/workshop. Townsville, James Cook University: James Cook University. p 11-23.

Coles R. 1992. Seagrass beds and juvenile prawn and fish nursery grounds: Cairns to Bowen. Brisbane, Australia: Queensland Department of Primary Industries.

Davies J, McKenna S, and Rasheed M. 2013. Port of Townsville long term seagrass monitoring: September 2012. Cairns, Australia: Centre for Tropical Water \& Aquatic Ecosytem Research (TropWATER) Publication, James Cook University. p 32.

Davies J, and Rasheed M. 2016. Port of Townsville Annual Seagrass Monitoring: September 2015. Cairns: James Cook University Publication, Centre for Tropical Water \& Aquatic Ecosystem Research (TropWATER). p 49.

De longh H, Kiswara W, Kustiawan W, and Loth P. 2007. A review of research on the interactions between dugongs (Dugong dugon Müller 1776) and intertidal seagrass beds in Indonesia. Hydrobiologia 591:73-83. 10.1007/s10750-007-0785-4

Grech A, Coles R, and Marsh H. 2011a. A broad-scale assessment of the risk to coastal seagrasses from cumulative threats. Marine Policy 35:560-567. 10.1016/j.marpol.2011.03.003

Grech A, Sheppard J, and Marsh H. 2011b. Informing species conservation at multiple scales using data collected for marine mammal stock assessments. PloS one 6:e17993. 10.1371/journal.pone.0017993

Green E, and Short F. 2003. World atlas of seagrasses: University of California Press.

Heinsohn G, Wake J, Marsh H, and Spain A. 1977. The dugong (Dugong dugon (Müller)) in the seagrass system. Aquaculture 12:235-248. 10.1016/0044-8486(77)90064-3

IUCN. 2011. IUCN Red List of threatened species. Gland, Switzerland: IUCN (International Union for Conservation of Nature) Global Species Programme Red List Unit. 
381 Johnstone I, and Hudson B. 1981. The dugong diet: mouth sample analysis. Bulletin of Marine Science

382

383

384

385

386

387

388

389

390

391

392

393

394

395

396

397

398

399

400

401

402

403

31:681-690.

Lanyon J. 1991. The nutritional ecology of the dugong, Dugong dugon, in tropical north Queensland PhD. Monash University.

Marsh H, Channells P, Heinsohn G, and Morrissey J. 1982. Analysis of stomach contents of dugongs from Queensland. Wildlife Research 9:55-67. 10.1071/WR9820055

Marsh H, De'ath G, Gribble N, and Lane B. 2005. Historical marine population estimates: triggers or targets for conservation? The dugong case study. Ecological Applications 15:481-492.

$10.1890 / 04-0673$

Marsh H, Grech A, and Hagihara R. 2012. Aerial survey of Torres Strait to evaluate the efficacy of an enforce and possibly extended Dugong Sanctuary as one of the tools for managing the dugong fishery. Canberra, Australia: Australian Marine Mammal Centre and the Torres Strait Regional Authority. p 33.

Marsh H, and Lefevbre L. 1994. Sirenian status and conservation efforts. Aquatic Mammals 20:155-155.

Marsh H, O'Shea T, and Reynolds III J. 2011. Ecology and conservation of the sirenia: dugongs and manatees: Cambridge University Press.

McKenna S, Jarvis J, Sankey T, Reason C, Coles R, and Rasheed M. 2015. Declines of seagrasses in a tropical harbour, North Queensland, Australia, are not the result of a single event. Journal of Biosciences 40:389-398. 10.1007/s12038-015-9516-6

McKenzie L, Collier C, and Waycott M. 2012. Reef Rescue Marine Monitoring Program-Inshore Seagrass, Annual Report for the sampling period 1st July 2010-31st May 2011. Cairns, Australia: Department of Employment, Economic Development and Innovation (Fisheries Queensland). $\mathrm{p}$ 41. 
404 McKenzie L, Collier C, and Waycott M. 2014. Reef Rescue Marine Monitoring Program - Inshore 405 Seagrass, Annual Report for the sampling period 1st July 2011 - 31st May 2012. Cairns: $406 \quad$ TropWATER, James Cook University. p 176.

407

408

409

410

411

412

413

414

415

416

417

418

419

420

421

422

423

424

425

426

427

Mellors J. 1991. An evaluation of a rapid visual technique for estimating seagrass biomass. Aquatic Botany 42:67-73. 10.1016/0304-3770(91)90106-F

Mellors J, Waycott M, and Marsh H. 2005. Variation in biogeochemical parameters across intertidal seagrass meadows in the central Great Barrier Reef region. Marine Pollution Bulletin 51:335342. 10.1016/j.marpolbul.2004.10.046

Orth R, Carruthers T, Dennison W, Duarte C, Fourqurean J, Heck K, Hughes R, Kendrick G, Kenworthy J, and Olyarnik S. 2006. A global crisis for seagrass ecosystems. Bioscience 56:987-996. 10.1641/0006-3568

Preen A. 1992. Interactions between dugongs and seagrasses in a subtropical environment PhD PhD Thesis. James Cook University.

Preen A. 1995. Impacts of dugong foraging on seagrass habitats: observational and experimental evidence for cultivation grazing. Marine ecology progress series Oldendorf 124:201-213.

Preen A. 1998. Marine protected areas and dugong conservation along Australia's Indian Ocean coast. Environmental Management 22:173-181. 10.1071/MF99080

Sheppard J, Carter A, McKenzie L, Pitcher R, and Coles R. 2008. Spatial patterns of sub-tidal seagrasses and their tissue nutrients in the Torres Strait, northern Australia: Implications for management. Continental Shelf Research 28:2282-2291. 10.1016/j.csr.2008.03.033

Sheppard J, Lawler I, and Marsh H. 2007. Seagrass as pasture for seacows: Landscape-level dugong habitat evaluation. Estuarine, Coastal and Shelf Science 71:117-132. 10.1016/j.ecss.2006.07.006

Sheppard J, Marsh H, Jones R, and Lawler I. 2010. Dugong habitat use in relation to seagrass nutrients, tides, and diel cycles. Marine mammal science 26:855-879. 10.1111/j.1748-7692.2010.00374.x 
428 Sheppard J, Preen A, Marsh H, Lawler I, Whiting S, and Jones R. 2006. Movement heterogeneity of

429

430

431

432

433

434

435

436

437

438

439

440

441

442

443

444

445 dugongs, Dugong dugon (Müller), over large spatial scales. Journal of Experimental Marine Biology and Ecology 334:64-83. 10.1016/j.jembe.2006.01.011

Short F, and Coles R. 2001. Global seagrass research methods. University of New Hampshire Durham, USA: Elsevier.

Sobtzick M, Hagihara R, Grech A, and Marsh H. 2012. Aerial survey of the urban coast of Queensland to evaluate the response of the dugong population to the widespread effects of the extreme weather events of the summer of 2010-2011. Published online by the Reef and Rainforest Centre Limited, Cairns, Australia: Final Report to the Australian Marine Mammal Centre and the National Environmental Research Program. p 62.

Triola M, and Triola M. 2006. Biostatistics for the Biological and Health Sciences. United States of America: Pearson Education.

Waycott M, McMahon K, Mellors J, Calladine A, and Kleine D. 2004. A guide to tropical seagrasses of the Indo-West Pacific. Townsville, Australia: James Cook University.

Whitlock M, and Schluter D. 2008. The analysis of biological data. Greenwood Villages, United States of America: Roberts and Company Publishers.

Wirsing A, Heithaus M, and Dill L. 2007. Fear factor: do dugongs (Dugong dugon) trade food for safety from tiger sharks (Galeocerdo cuvier)? Oecologia 153:1031-1040. 10.1007/s00442-007-0802-3 


\section{Figure 1}

Figure 1

Seagrass collection and dugong feeding observation sites in the Great Barrier Reef, northeast Queensland Australia; locator map of Australia with Townsville and Cairns highlighted. 


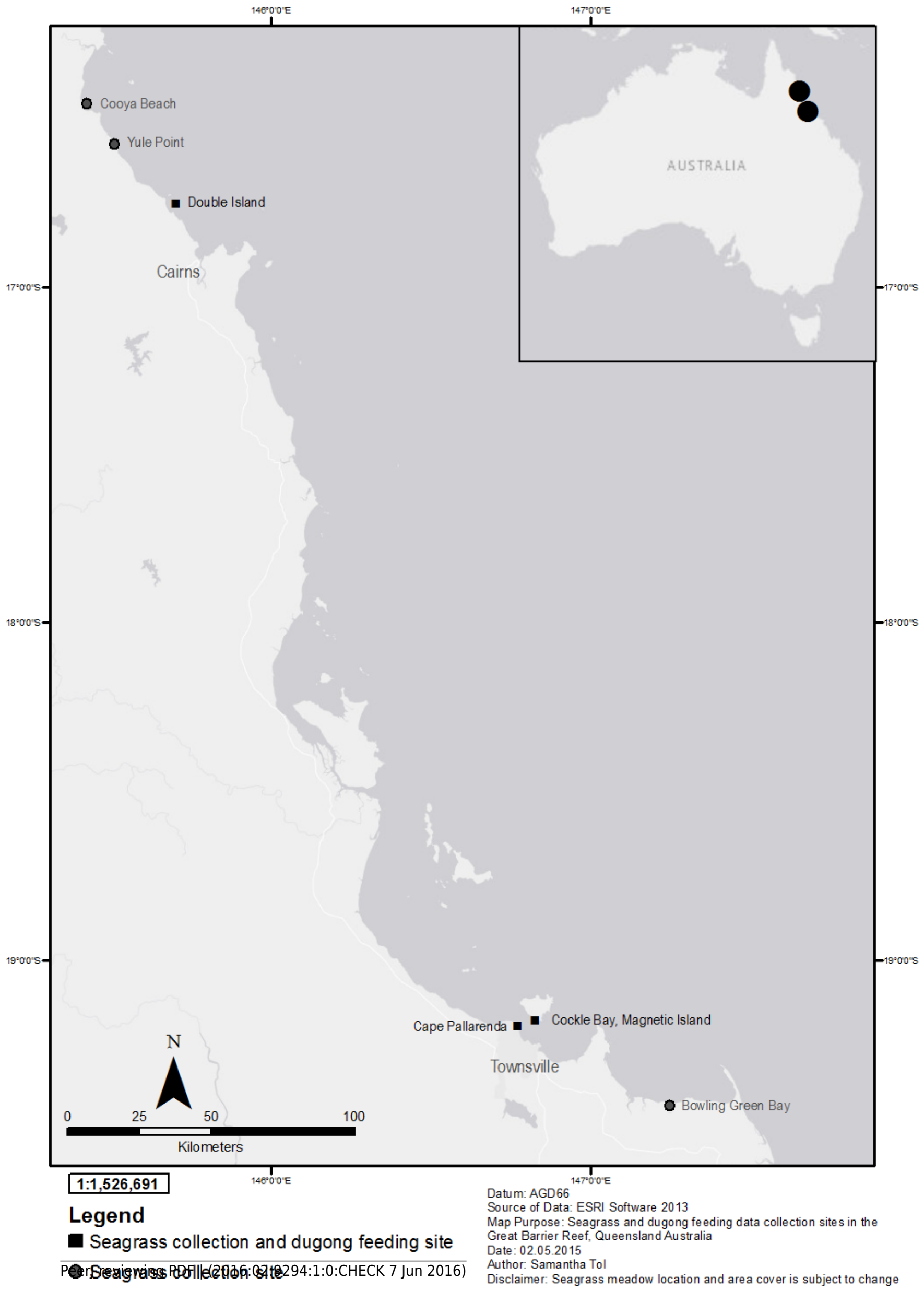




\section{Figure 2}

Figure 2

a) Dugong feeding trails in a mixed species intertidal seagrass meadow at low tide taken at Cape Pallarenda, Australia on the 02/07/2012; and b) a dugong feeding trail through Cymodocea rotundata and Halophila ovalis seagrass at Cockle Bay, Magnetic Island Australia taken on the $29 / 07 / 2012$.

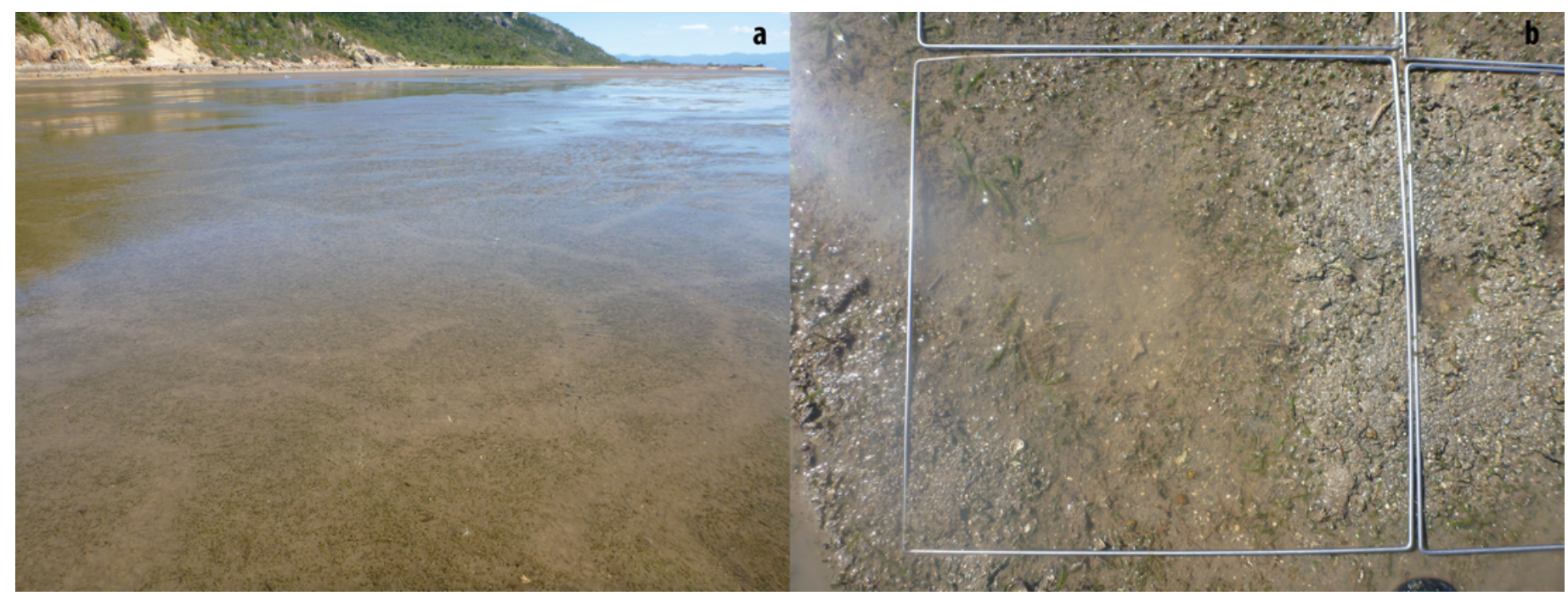




\section{Figure 3}

Figure 3

Whole plant nitrogen weight $(\mathrm{mg} / \mathrm{g})$ for seagrass species across different seagrass meadows along the Great Barrier Reef, north-east Queensland Australia; a) Halodule uninervis (HU) and Halophila ovalis $(\mathrm{HO})$ are not significantly different between species (ANOVA: $\mathrm{F}=$ $0.29005_{1,3}, p=0.59$ ), however nitrogen varied significantly across sites (ANOVA: $F=31.94_{, 3}$, $p=>0.001)$; b) Cymodocea spp. did not differ in nitrogen concentration across the two sites it was present (Wilcoxin rank sum: $Z=12, n=3, p=0.70$ ). 

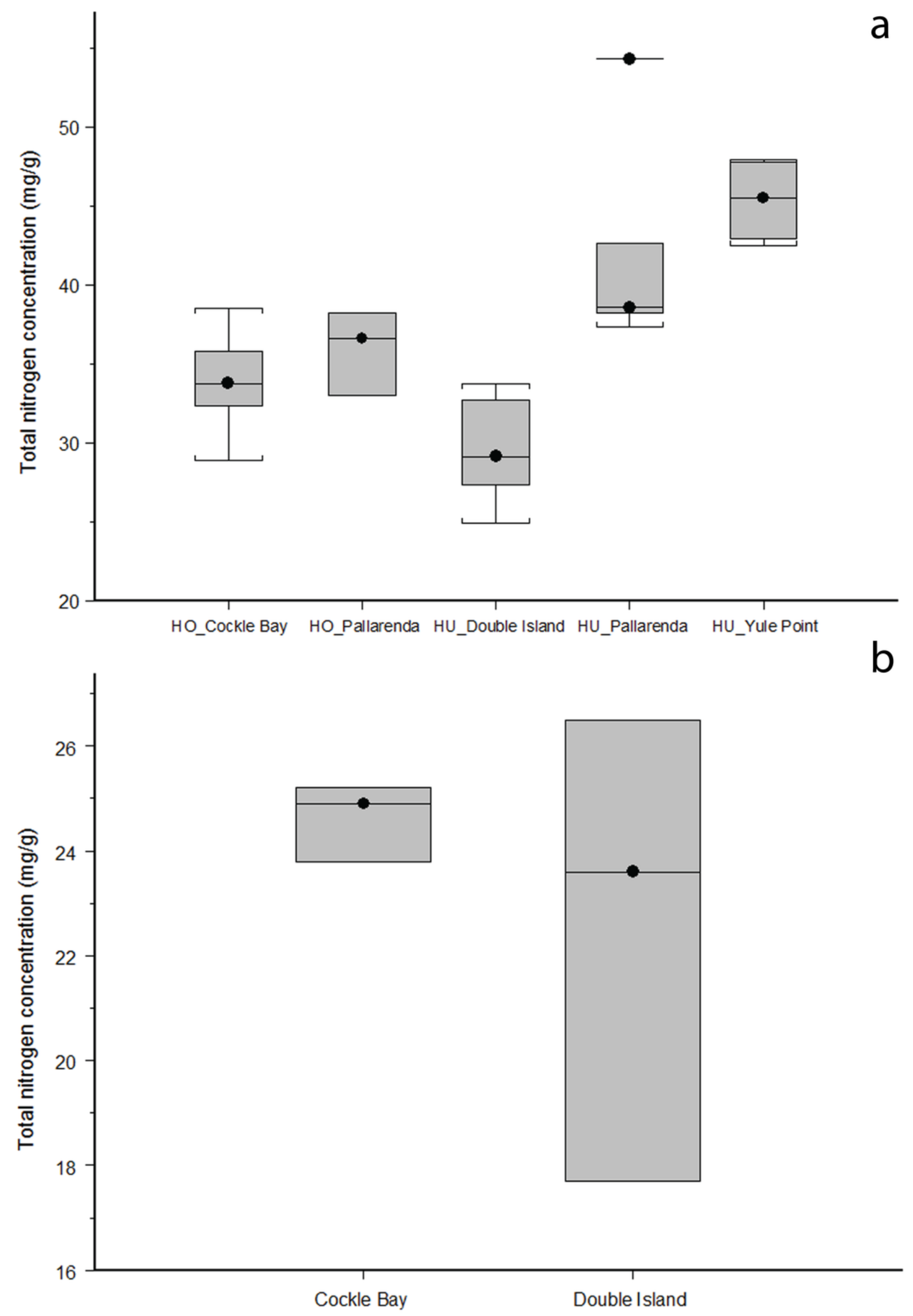


\section{Figure 4}

Figure 4

As the available seagrass biomass $\left(\mathrm{g} / \mathrm{DW} \mathrm{m}^{2}\right)$ increases the amount of seagrass biomass consumed by dugong's increases proportionally for four seagrass species. There is no difference between feeding on Cymodocea spp. to Halophila ovalis, Halodule uninervis and S. isoetifolium ( $H$. ovalis: Linear Mixed-Effect model fit by REML: $t=-0.88013, p=0.3797 ; H$. uninervis: Linear Mixed-Effect model fit by REML: $t=-1.01145, p=0.3129 ;$ S. isoetifolium, Linear Mixed-Effect model fit by REML: $t=-0.63097, p=0.5287$ ), however Thalassia hemprichii had greater feeding as biomass increased (Linear Mixed-Effect model fit by REML: $t=2.06871, p=0.0397)$; the $y$-axis has been back-transformed for graphical purposes, and the insert graph is a close up of data points from 0.00 to $0.12 \mathrm{~g} / \mathrm{DW} \mathrm{m}^{2}$ seagrass biomass available. Data was taken between May to August 2012 from three intertidal seagrass meadows in the Great Barrier Reef, north-east Queensland, Australia; Double Island, Cape Pallarenda and Cockle Bay at Magnetic Island. 


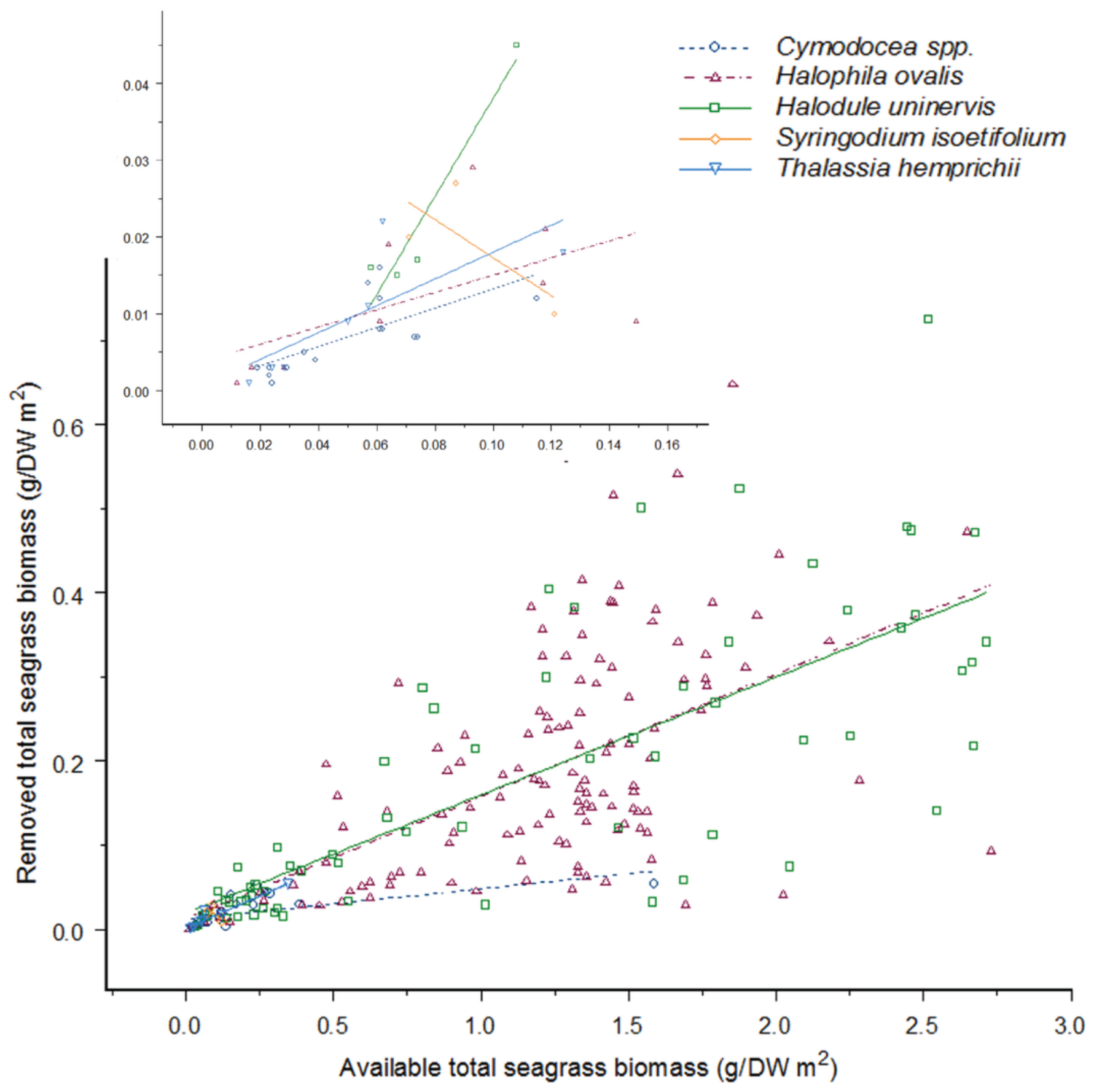




\section{Table $\mathbf{1}$ (on next page)}

Table 1

Description of seagrass meadow study sites identifying sediment type, species present and average per cent cover $\left(\mathrm{m}^{2}\right)$ and biomass $\left(\mathrm{g} / \mathrm{DW} \mathrm{m}^{2}\right)$; per cent cover and biomass was measured over an area ranging from $1000-1500 \mathrm{~m}^{2}$ over a 4-month period. Date collected during March to July 2012 of six intertidal seagrass meadows along the Great Barrier Reef in the north-east Queensland, Australia. 
1 Table 1: Description of seagrass meadow study sites identifying sediment type, species present and average per cent cover $\left(\mathrm{m}^{2}\right)$ and

2 biomass $\left(\mathrm{g} / \mathrm{DW} \mathrm{m}^{2}\right)$; per cent cover and biomass was measured over an area ranging from $1000-1500 \mathrm{~m}^{2}$ over a 4-month period.

3 Date collected during March to July 2012 of six intertidal seagrass meadows along the Great Barrier Reef in the north-east

4 Queensland, Australia.

\begin{tabular}{|c|c|c|c|c|c|c|}
\hline Seagrass Meadow & Sediment & Species Present & $\begin{array}{l}\text { Average Species } \\
\text { \% Cover }\left(\mathrm{m}^{2}\right)\end{array}$ & SE & $\begin{array}{l}\text { Average Biomass } \\
\left(\mathrm{g} / \mathrm{DW} \mathrm{m}^{2}\right)\end{array}$ & SE \\
\hline \multirow[t]{4}{*}{ Cooya Beach } & \multirow[t]{4}{*}{ Mud and sand } & Enhalus acoroides & NR & & NR & \\
\hline & & Halodule uninervis & NR & & NR & \\
\hline & & Halophila ovalis & NR & & NR & \\
\hline & & Zostera muelleri & NR & & NR & \\
\hline \multirow[t]{2}{*}{ Yule Point } & \multirow[t]{2}{*}{ Sand } & Halodule uninervis & NR & & NR & \\
\hline & & Halophila ovalis & NR & & NR & \\
\hline \multirow[t]{5}{*}{ Double Island, Reef Flat } & Coarse sand, coral & Cymodocea spp. & 4.419 & \pm 1.327 & 0.239 & \pm 0.051 \\
\hline & \multirow[t]{4}{*}{ rubble and mud } & Halodule uninervis & 73.566 & \pm 2.709 & 0.586 & \pm 0.043 \\
\hline & & Halophila ovalis & 20.559 & \pm 2.558 & 0.124 & \pm 0.016 \\
\hline & & Syringodium isoetifolium & 0.118 & \pm 0.060 & 0.060 & \pm 0.022 \\
\hline & & Thalassia hemprichii & 0.831 & \pm 0.298 & 0.179 & \pm 0.037 \\
\hline \multirow[t]{2}{*}{ Cape Pallarenda } & \multirow[t]{2}{*}{ Sand and mud } & Halodule uninervis & 38.038 & \pm 2.144 & 1.298 & \pm 0.088 \\
\hline & & Halophila ovalis & 61.962 & \pm 2.144 & 0.636 & \pm 0.018 \\
\hline Cockle Bay, Magnetic & Sand, coral rubble & Cymodocea spp. & 2.733 & \pm 0.456 & 0.229 & \pm 0.033 \\
\hline
\end{tabular}




\begin{tabular}{|c|c|c|c|c|c|c|}
\hline \multirow[t]{3}{*}{ Island } & and mud & Halodule uninervis & 1.698 & \pm 0.418 & 0.363 & \pm 0.087 \\
\hline & & Halophila ovalis & 95.276 & \pm 0.570 & 0.797 & \pm 0.014 \\
\hline & & Thalassia hemprichii & 0.293 & \pm 0.126 & 0.318 & \pm 0.111 \\
\hline \multirow[t]{3}{*}{ Bowling Green Bay } & Mud and sand & Halodule uninervis & NR & & NR & \\
\hline & & Halophila ovalis & NR & & NR & \\
\hline & & Zostera muelleri & NR & & NR & \\
\hline
\end{tabular}

5

$6 \quad \mathbf{N R}=\mathbf{N o t}$ recorded 


\section{Table 2 (on next page)}

Table 2

Means and standard error of nitrogen weight of seagrass weight $(\mathrm{mg} / \mathrm{g})$ for the above ground (leaf and leaf sheaths), below ground (roots and rhizomes) and whole plant of seagrass species within six intertidal seagrass meadows along the Great Barrier Reef, north-east Queensland, Australia. Samples collected during March to July 2012. 
1 Table 2: Means and standard error of nitrogen weight of seagrass weight $(\mathrm{mg} / \mathrm{g})$ for the above

2 ground (leaf and leaf sheaths), below ground (roots and rhizomes) and whole plant of seagrass

3 species within six intertidal seagrass meadows along the Great Barrier Reef, north-east

4 Queensland, Australia. Samples collected during March to July 2012.

\begin{tabular}{lcccccc}
\hline Site & Above ground & Below ground & Total plant \\
\hline $\begin{array}{l}\text { Double Is. } \\
\text { Cymodocea serrulata }\end{array}$ & 16.2 & \pm 2.2 & 3.9 & \pm 0.5 & 22.6 & \pm 2.6 \\
Halophila ovalis & ID & & ID & & ID & \\
Halodule uninervis & 23.0 & \pm 2.3 & 6.5 & \pm 0.9 & 29.5 & \pm 2.8 \\
Syringodium isoetifolium & 20.1 & \pm 0.6 & 9.4 & \pm 0.3 & 29.5 & \pm 0.9 \\
Thalassia hemprichii & ID & & ID & & ID &
\end{tabular}

Yule Point beach

\begin{tabular}{lllllll} 
Halophila ovalis & ID & \multicolumn{3}{c}{ ID } & \multicolumn{3}{c}{ ID } \\
& & & & & & \\
Halodule uninervis $^{a}$ & 39.8 & \pm 4.2 & 7.0 & \pm 1.6 & 46.9 & \pm 2.2
\end{tabular}

Cooya beach

\begin{tabular}{|c|c|c|c|c|}
\hline Enhalus acoroides ${ }^{b}$ & 19.8 & 11.7 & \pm 2.0 & 31.7 \\
\hline Halophila ovalis & ID & ID & & ID \\
\hline Halodule uninervis & ID & ID & & ID \\
\hline Zostera muelleri & ID & ID & & ID \\
\hline
\end{tabular}

Cockle Bay, Magnetic Is.

$\begin{array}{lcccccc}\text { Cymodocea serrulata } & 18.8 & \pm 0.5 & 5.9 & \pm 0.4 & 24.6 & \pm 0.4 \\ \text { Halophila ovalis } & 27.5 & \pm 3.0 & 6.4 & \pm 0.7 & 33.9 & \pm 3.0 \\ \text { Halodule uninervis } & \text { ID } & & \text { ID } & & \text { ID } & \end{array}$


$\begin{array}{lllllll}\text { Thalassia hemprichii } & 19.9 & \pm 2.4 & 8.1 & \pm 0.3 & 27.9 & \pm 2.8\end{array}$

Cape Pallarenda

$\begin{array}{lcccccc}\text { Halophila ovalis } & 29.1 & \pm 1.9 & 6.8 & \pm 0.4 & 35.9 & \pm 1.5 \\ \text { Halodule uninervis } & 34.6 & \pm 7.0 & 7.0 & \pm 1.6 & 41.6 & \pm 8.1\end{array}$

Bowling Green Bay

Halodule uninervis

ID

ID

ID

Zostera muelleri

$25.6 \pm 3.1 \quad 7.0$

$\pm 3.7$

$32.6 \pm 5.2$

$5 \quad$ ID $=$ Insufficient data

$6 \quad{ }^{a}$ Above ground results based on 5 samples; below ground and total results based on 4 samples

$7 \quad{ }^{b}$ Above ground results based on 11 samples; below ground and total results based on 10 samples 8 